\title{
Indocile Bodies: Gender Identity and Strip Searches in Canadian Criminal Law
}

Kyle Kirkup

\section{Introduction}

What happens when non-normative genders and sexualities collide with the complicated world of criminal procedure? What might the criminal justice system's treatment of trans persons reveal about our deep-seated anxieties about bodies, genders, and sexualities? How might strip searches represent a larger series of coercive mechanisms used to dissuade members of society from breaking from traditionally accepted "norms"? And what strategies might we use to resist these constrictive systems of power? To answer these questions, I ground 'my analysis in a close reading of a 2006 Canadian case, Forrester v. Peel (Regional Municipality) Police Services Board.'

In this case, Rosalyn Forrester brought an Ontario Human Rights Code $(\mathrm{OHRC})^{2}$ complaint against the Peel Police Services Board, alleging repeated acts of discrimination in services on the basis of sex. Forrester was a preoperative male-to-female (MTF) trans woman who claimed she had been questioned, mocked, incarcerated, and inappropriately strip-searched following a series of arrests. While Forrester repeatedly requested that female officers perform these searches, her requests were denied. During two searches, male officers performed the strip searches alone. On one other occasion, male and female officers performed a "split search." During the "split search," male officers examined Forrester's "male" lower body while female officers inspected her "female" upper body.

Drawing on insights gleaned from Forrester, I argue that strip searches exist as part of a larger system of power, a system in which bodies, genders, and sexualities outside the socially constructed "norm" are routinely subjected to discipline and punishment. Trans bodies are targeted not merely because they are perceived as different but also because of what that difference symbolizes: a failure of the regimes that regulate bodies into a sharp, essentialist gender binary. As such, trans bodies become a key site for

* The author thanks Graham Mayeda and Elizabeth Sheehy for their comments on earlier drafts of this article. He also thanks Mariana Valverde and the three anonymous reviewers who provided thoughtful suggestions for revision. Finally, he thanks Jerald Sabin for his support throughout this project.

1 [2006] H.R.T.O. 13 [Forrester].

2 R.S.O. 1990 , c. H.19.

Canadian Journal of Law and Society / Revue Canadienne Droit et Société, 2009, Volume 24, no. 1, pp. 107-125 
simultaneous observation, normalization, and examination not only by the police but also by society at large.

\section{The Law of Strip Searches in Canada}

Golden $(2001)^{3}$ is the Supreme Court of Canada's leading case on strip searches and, as such, provides a useful starting point for my analysis. lan Vincent Golden was arrested after the police believed they had observed him crushing crack cocaine between his fingers. After detaining him, a police officer conducted a "pat-down" search of Golden's body, which found no weapons or narcotics. At this point, the officer conducted a visual inspection of Golden's underwear and buttocks in a stairwell leading to a basement where public washrooms were located. The officer then undid Golden's pants, at which point he noticed a clear plastic package covering a white substance protruding from Golden's buttocks. Officers then forced Golden to bend over a table with his pants and underwear pulled down. Encountering difficulty when they attempted to pull the package from his buttocks, the officers eventually retrieved a pair of used nubber dishwashing gloves, which one of them wore while dislodging the package. The officers were finally able to remove the package, which contained 10.1 grams of crack cocaine. Golden was then charged with possession of a narcotic for the purpose of trafficking and with police assault. He was again strip-searched at the police station as a "security measure." The majority of the Court held that the warrantless strip search imposed on Golden was conducted in an unreasonable manner and, thus, infringed his s. 8 Charter rights. ${ }^{5}$ The majority therefore excluded the evidence obtained as a result of the strip search under s. 24 of the Charter. ${ }^{6}$ The standard now is that a strip search can be performed only if the police or other government officials have reasons for the search beyond the "reasonable grounds" that led to the person's detainment.

In its analysis, the Court defined the term "strip search" as "the removal or rearrangement of some or all of the clothing of a person so as to permit a visual inspection of a person's private areas, namely genitals, buttocks, breasts (in the case of a female), or undergarments."7 While the Court's definition excluded a trans person who, for example, might self-identify as female but not have breasts, the Court recognized that strip searches may be particularly intrusive for women and minorities. Iacobucci and Arbour JJ., representing the majority of the Court, stated, "Women and minorities in particular may have a real fear of strip searches and may experience such a search as equivalent to a sexual assault." While the Court recognized the particularly intrusive nature of strip searches for historically marginalized groups, trans

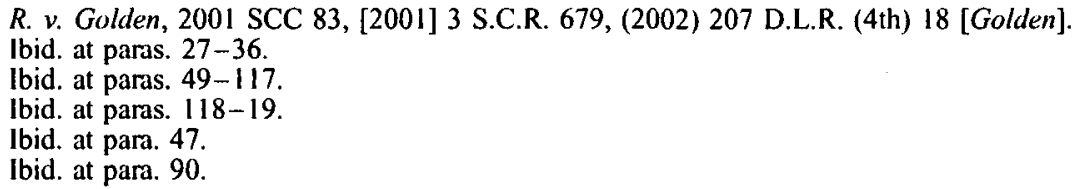


individuals are never mentioned. Forrester, it seems, works to fill the gap left by Golden.

Rosalyn Forrester filed an OHRC complaint against the Peel Police Services Board in 2003 because of strip searches she had undergone in 1999. The strip searches of Forrester occurred in the pre-Golden era, when police often strip-searched arrestees as a "security measure." As noted above, in some instances Forrester's strip searches were conducted exclusively by male police officers, while in another instance, a "split search" was conducted during which male officers examined Forrester's still intact penis while female officers inspected her breasts, which were developing as a result of hormone-therapy treatments. Forrester claimed that she "repeatedly requested female officers to perform these searches, but that her requests were denied." 10

In 2002, after the Golden decision was released, the Peel Police Services Board enacted a policy to advise officers that strip searches were prohibited absent reasonable and probable grounds. The board also enacted a policy entitled "Strip Searching Transsexuals," which stated,

Officers have encountered individuals who have been in the process of changing their outward sexual organs from male to female. Sometimes these individuals have received breast augmentation or hormone treatments to increase their breast size. If there is reasonable grounds to strip search these individuals, a female officer should search the top half of the individual and a male officer should search the genital area of the individual, as the case may be. Each individual set of circumstances should be viewed independently. Common sense should dictate, with a view of maintaining the individuals [sic] privacy and person [sic] integrity."

The policy stated that officers should question the person about to be searched in order to determine his or her gender status; when in doubt, the officer-incharge would make the final decision on the detained person's "degree of gender alteration."12

At the beginning of the hearing, the Peel Police Services Board argued that its 2002 policy on "split searches" was "sufficient to meet its obligations under the Code, and argued that it was more than what other police forces do to accommodate transsexuals who are being strip-searched." 13 Just prior to closing submissions, however, counsel for the board explained that "her client had had an epiphany of sorts" and "admitted liability under the Code, stating that it had unintentionally discriminated against Ms. Forrester." ${ }^{\text {14 }}$ Counsel for the Police Services Board explained to the Ontario Human Rights Commission that it had settled with Forrester with respect to

Forrester at para. 3.

Ibid. at para. 1.

Ibid. at para. 4.

Ibid. at para. 5.

Ibid. at para. 6 .

Ibid. at para. 16 
remedies. Therefore, the commission decided to "strive to issue a decision that is hopefully inspirational to other police forces across Ontario which may lack policies on searching transsexual persons." 15

The commission narrowed the complicated series of events into five central questions. Four of these questions relate to procedural aspects of trans strip searches, while the last deals with the development and implementation of education programs for police officers:

(i) Should the Respondent be required, as it has voluntarily proposed, to give a male or female transsexual a choice of being searched by a male or female officer or given a split search?

(ii) If there is any dispute between the officer and the detainee about whether or not the detainee is transsexual, should the detainee have to answer some prescribed questions in order to validate his or her commitment to transitioning and to eliminate potential false claims?

(iii) If there is a dispute between the officer and the detainee about the validity of the detainee's self-disclosure as a transsexual, who should make the final decision prior to the search, the Officer-inCharge, or the detainee?

(iv) If an officer is of the same sex as the transsexual detainee, and the officer feels uncomfortable performing the search, can that officer "opt out" without sanction if another officer of the same sex is available to perform the strip-search without delay?

(v) Should the proposed education and training for new officers on performing strip-searches on transsexuals be extended to include all existing officers? If so, how? ${ }^{16}$

A full treatment of these complicated legal issues and their connection to criminal procedure in Canada goes beyond the scope of my analysis. However, a few brief comments on each of these five issues may be helpful here.

\section{(i) Choice of male officer(s), female officer(s), or "split search"}

First, the Human Rights Commission rejected the policy of performing "split searches" in cases of individuals with a so-called male lower half and female upper half (or vice versa). Rather, the commission stated that Peel would have to revise its policy such that transsexual detainees would be offered three options with respect to who would perform the strip search: male officer(s) only, female officer(s) only, or a "split search." the extent to which Forrester was psychologically injured by the male-only and "split searches" when she self-identified as a woman.

\section{(ii) Dispute between officer and detainee regarding transsexual status}

The Human Rights Commission stated that before a strip search is conducted, "an officer must explain the process, take notes prior to conducting the search 
including the choice made by a transsexual detainee, and notify his or her Officer-in-Charge who will authorize the strip-search."18 To gain access to the three options, then, the detainee must first be identified as transsexual. The respondent in Forrester recognized that it would often be "possible to recognize or accept a transsexual on self-identification, particularly if doing so will secure the detainee's cooperation." ${ }^{19}$ However, the parties disagreed about how best to proceed in cases in which police officers doubted the detainee's self-identification. The commission ordered that, when an officer has "serious reason to doubt a detainee's self-identification as a transsexual," the officer be permitted to ask the detainee several questions in private to "verify the detainee's status."

\section{(iii) The final "gender determination"}

The Human Rights Commission expressed confidence that, having asked the self-identified transsexual person several questions, the police officer will have a good sense of the detainee's gender status and stated that if, after asking the questions, the officer "continues to have serious reason to doubt the detainee's self-identification, the officer shall defer to the Officer-inCharge of the Division for a final determination."21 The commission accepted evidence given on behalf of the Peel Police Services Board that police officers often find large and dangerous weapons on the bodies of detainees. Apparently, the police worried that detainees might begin to falsely identify themselves as trans in order to have female police officers conduct their strip searches; for this reason, it was important for the police to have the final word regarding the "gender determination." The commission accepted the claim that officer safety would be compromised if the police did not have the final word. ${ }^{22}$ This claim is problematic, however, for three reasons. First, the commission's finding does not accord with the statement of Iacobucci and Arbour JJ. in Golden that a "'frisk' or 'pat-down' search at the point of arrest will generally suffice for the purposes of determining if the accused has secreted weapons on his person."23 Second, the commission seems to have shown unnecessary deference to the police board's invocation of officer safety without acknowledging the concerns raised by Forrester. Third, the decision implies a lack of confidence in the ability of female police officers to disarm detainees, should the need arise, without the assistance of male officers.

18 Ibid. at para. 476.

19 lbid. at para. 431 .

20 Ibid. at para. 476. Unfortunately, the Human Rights Commission's opinion is silent as to what sorts of cues might lead police officers to seriously doubt the detainee's selfidentification. Ibid.

22 Ibid. at paras. $440-42$

23 Golden at para. 94. 


\section{Kyle Kirkup}

\section{(iv) Police officer "opt-outs"}

Having mapped out the procedural requirements for trans strip searches, the Human Rights Commission then dealt with the contentious issue of whether or not a police officer should be able to opt out of performing searches where another officer can easily be substituted. While the Peel Police Services Board argued that officers should be allowed to opt out, both Forrester and the commission counsel argued that they should not. On this point, the commission took its cue from s. 9 of the OHRC, which states that "[n]o person shall infringe or do, directly or indirectly, anything that infringes a right under this Part." ${ }^{24}$ The commission held that allowing officers to opt out would, in effect, sanction a "chain of discrimination" against the transsexual community, given that "no equivalent 'opt out' is provided against anyone else." ${ }^{35}$ In the end, the commission's decision provides that -in very limited circumstances - officers can opt out: the officer-incharge is permitted to "relieve an officer of his or her duties" if the officer has "significant Code or Charter interests of his or her' own to protect, and if the substitution and the reason for it is authorized and documented by the Officer-in-Charge."26 Unfortunately, the commission failed to provide examples of the OHRC or Charter interests that police officers might need to protect by refusing to strip-search trans individuals.

\section{(v) Education strategies}

Finally, the Human Rights Commission outlined the development and implementation of education programs that would teach police officers how to act more sensitively, noting that "virtually all of the officers involved" stated that they had never discussed trans issues during their diversity-training sessions. To remedy this situation, the commission ordered the Police Services Board to produce "a training video on transsexuality for all members of its force, in conjunction with various experts, and with input from the transsexual community, including Ms. Forrester if she is willing to participate, to be approved by the Commission prior to implementation."27 The video was to be shown to all officers, accompanied by the amended directive explaining the change in policy. The commission ordered that the "revised Directive, training video and implementation shall occur within six months of the date of this Order.",

\section{Foucault's Discipline and Punish and the Indocile Trans Body}

\section{Foucault's method}

If we were to pull back the layers of Forrester and, in the process, connect the actions of the police to larger systems of power, what might be revealed? This

Forrester at para. 459 [emphasis added by the Human Rights Commission].

Ibid. at para. 463 .

Ibid. at para. 476

Ibid.

Ibid. 
sort of question is precisely what intrigued Michel Foucault. ${ }^{29}$ In Discipline and Punish, ${ }^{30}$ Foucault purports to trace the historical emergence of the modern prison during the eighteenth century. In the process, however, he unmasks a larger history of the present, a history that ends up controlling and dominating the wills and inclinations of human beings through the perpetual surveillance of the body. Foucault reveals this account of power using a unique method, one that I propose to use to help illuminate the strip searches performed on Rosalyn Forrester.

Several commentators have attempted to articulate Foucault's method, often finding themselves enmeshed in complicated debates about the relationship between his archaeological and his genealogical methods. Instead of participating in these debates, I will simply provide what I consider the clearest description of Foucault's method, which comes from Gavin Kendall and Gary Wickham. Describing genealogy, Kendall and Wickman write,

It is, in other words, a methodological device with the same effect as a precious child at a dinner party: genealogy makes the older guests at the table of intellectual analysis feel decidedly uncomfortable by pointing out things about their origins and functions that they would rather remain hidden.

In analysing a particular problem, such as the creation of the modern prison in Discipline and Punish, Foucault's method involves scouring the annals of history in search of each and every object that might reveal something about our present condition. From architectural styles to historical documents to first-person narratives, nothing is off limits. When brought together, these diverse artefacts-which might not have appeared to have any

29 Foucault's method has received considerable scholarly attention, and debates are ongoing. See, e.g., Michel Foucault, "Questions of Method," in The Foucault Effect: Studies in Governmentality, ed. Graham Burchill et al. (Chicago: University of Chicago Press, 1991); Paul Brass, "Foucault Steals Political Science," Annual Review of Political Science 3 (2000), 305; Mitchell Dean, Governmentality: Power and Rule in Modern Society (Thousand Oaks, CA: Sage Publications, 1999); Michel Foucault, "Nietzsche, Genealogy, History," in Aesthetics, Method, and Epistemology: Essential Works of Foucault, 1954-1984, vol. 2, ed. James D. Faubion (New York: W.W. Norton, 2006); Wendy Brown, Politics Without History (Princeton, NJ: Princeton University Press, 2001).

30 Michel Foucault, Discipline and Punish: The Birth of the Prison, trans. by Alan Sheridan (New York: Vintage Books, 1977).

31 For an interesting discussion of the relationship between Foucaultian agency and power see, e.g., Judith Butler, Bodies That Matter: On the Discursive Limits of "Sex" (New York: Routledge, 1993). As Butler puts it, there is no position outside the field of power. She poses a number of questions about the relationship between power and individual agency: Given that there is no sexuality outside of power, how can regulation itself be construed as a productive or generative constraint on sexuality? Specifically, how does the capacity of the law to produce and constrain at once play itself out in the securing for every body a sex, a sex position in language, a sexed position which is in some sense presumed by any body who comes to speak as a subject, an "I," one who is constituted through the act of taking its sexed place within a language that insistently forces the question of sex? (Ibid., 95)

32 Gavin Kendall and Gary Wickham, Using Foucault's Methods (Thousand Oaks, CA: Sage Publications, 1999), 29. 


\section{Kyle Kirkup}

significance on their own-begin to reveal hidden, often uncomfortable histories about ourselves.

If we were to search for artefacts that might help reveal hidden histories of bodies, genders, and sexualities dwelling outside socially constructed, contingent "norms," what might we find? In this section I do not purport to conduct an empirical study of the treatment of bodies, genders, and sexualities in Canada; instead, I am interested in situating the treatment of Rosalyn Forrester within a larger matrix of power, one in which legal mechanisms often become a key site in the exercise of coercive control. ${ }^{33}$ While I have not scoured the annals of history with quite the same rigour as Foucault, I nonetheless conceptualize my analysis as Foucaultian. By pulling apart contemporary legal artefacts, I hope to expose regimes of coercive control that often violently reveal themselves upon the human body.

\section{Recent legal artefacts related to strip searches}

The treatment of Rosalyn Forrester does not exist in a vacuum. Rather, her experience must be read as part of a larger history of the present in which bodies, genders, and sexualities outside the "norm" are often scrutinized and abused by the police. Two cases that help illuminate the coencive, intrusive measures taken by the police are $R$. v. Grenke $(2004)^{34}$ and $R$. v. Hornick (2002). ${ }^{35}$ It is important to note that both of these cases were decided recently, in a post-Golden context. Also, the relatively small amount of jurisprudence relating to strip searches does not mean that abuse does not occur on a regular basis. As is often the case when there is a gross power imbalance between minority populations and the police, instances of abuse regularly go unreported, often out of fear or because of victims' limited financial resources. ${ }^{36}$

In Grenke, the complainant, Shawn Grenke, testified that he was kicked by one of the officers who strip-searched him and that he was also "subjected to anti-gay slurs." ${ }^{37}$ He further testified that one officer yelled out phrases such as "be a man" and "girly boy" as he kicked and strip-searched Grenke. ${ }^{38}$ The Court rejected the accusations made by the Grenke and, using a particularly gendered, feminized phrase, found that he was "prone to exaggeration." ${ }^{39}$ In addition, the Court noted that the two officers confirmed each other's

33 For an in-depth discussion of homophobic violence in Canada see, e.g., Douglas Janoff, Pink Blood: Homophobic Violence in Canada (Toronto: University of Toronto Press, 2005); Thomas Fleming, "Criminalizing a Marginal Community: The Bawdy-House Raids," in Deviant Designations: Crime, Law and Deviance in Canada, ed. Thomas Fleming and L.A. Visano (Toronto: Butterworths, 1983), 37.

352002 O.J. No. 1170,93 C.R.R. (2d) 261, 53 W.C.B. (2d) 275 [Hornick].

36 For a discussion of reporting problems and the difficulty of evidentiary burdens in the context of racial profiling claims see, e.g., David M. Tanovich, The Colour of Justice: Policing Race in Canada (Toronto: Irwin Law, 2006). 
stories, which added credibility to their version of events at the expense of Grenke's version. ${ }^{40}$

While we cannot be sure about what happened in the room during the strip search, the reasoning of the Court demonstrates that when two police officers adopt the same story, the accused will have great difficulty in demonstrating police deployment of physical and verbal abuse. Do accused persons who are attacked and subjected to homophobic slurs during strip searches simply choose to say nothing, rather than try to challenge the credibility of the police $?^{41}$ Does this result in the escalation of inappropriate, homophobic police conduct that society might mistakenly view as a historical anomaly?

Conversely, Hornick-which also involved a "raid" on non-normative genders and sexualities-shows that when more witnesses can be called to demonstrate police abuses during strip searches, those dwelling in bodies, genders, and sexualities outside the "norm" may successfully challenge the power of the police. In this case, two female police officers performed an undercover investigation at the Pussy Palace, a bathhouse that permitted only women and trans people (both MTF and FTM) to enter. Later in the evening, five male police officers entered what they had been told was a "highly sexualized" environment, with women and trans people in various states of undress. They claimed to be there to investigate violations of the establishment's liquor licence. ${ }^{42}$ The Court held that because the event was open only to women and trans people, the act of male police officers entering the establishment was analogous to a strip search for those attending the Pussy Palace. The participants had a reasonable expectation that only women and trans people would be permitted to enter the establishment. ${ }^{43}$

Police forces have played an important role in regulating bodily "norms," particularly those related to genders and sexualities. Given both historical and contemporary clashes between the trans community and police forces, it is not surprising that Rosalyn Forrester encountered discrimination and marginalization when she was strip-searched. Thus, Forrester's experiences with the criminal justice system may be part of a larger pattern of abuse at the hands of the police. $^{44}$ But legal discourse only partially illuminates the systems that engulfed the body of Rosalyn Forrester. Taking up Foucault's method, the question I pose is this: What might the strip searches imposed on Rosalyn Forrester reveal to us about bodies, genders, and sexualities dwelling in

$40 \quad$ Ibid. at para. 29.

4) The Court rejected Grenke's argument that the only remedy capable of addressing the breach of his Charter rights was a stay of proceedings, as the breach had no impact on the fairness of his trial. However, the Court held, at para. 40 , that "[b]y being illegally strip searched, the applicant has, in a sense, already paid a penalty for the offences. Sentencing courts routinely take such extra-judicial consequences into account in determining appropriate dispositions."

43 Hornick at para. 5.

43 Ibid. at paras. 20-55.

44 For a fuller discussion of contemporary clashes between those dwelling in non-normative genders and sexualities and the police see, e.g., Stephen Whittle, Respect and Equality: Transsexual and Transgender Rights (London: Cavendish Publishing, 2002), especially "The Praxis and Politics of Policing: Problems Facing Trans People," 203. 
non-normative positions? Using Foucault's own language, let us attempt to construct a genealogy of Rosalyn Forrester, a genealogy that is "situated within the articulation of the body and history" and whose task is to expose "a body totally imprinted by history and the process of history's destruction of the body." 45

\section{Normalizing Bodies, Genders, and Sexualities}

\section{Indocile trans bodies}

In Discipline and Punish, Foucault contends that, beginning in the eighteenth century, productive forces began to coercively engulf the human body. The body became a site of transformation-through its "harnessing" and "fixing," human wills, impulses, and inclinations could be stifled in favour of imposed normalization. And so, in the modern era, bodies became docile; they could be "subjected, used, transformed and improved." 46 For Foucault, the physicality of the new paradigm is important: power began to manifest itself, often in violent ways, upon the body. While Foucault never reveals precisely why power insists on the continuance of sharp, essentialist gender binaries, Judith Butler takes up this question in Gender Trouble. For Butler, gender binaries support the continuance of heterosexual coherence. As she puts it, a nonnormative performance of gender "reveals the distinctness of those aspects of gendered experience which are falsely naturalized as a unity through the regulatory fiction of heterosexual coherence." ${ }^{, 7}$ Thus, gender binaries help to reinforce the naturalized, hegemonic status of heterosexuality.

Returning to Foucault, we can find a striking example of the production of docile bodies by examining historical representations of soldiers' bodies. The paradigmatic soldier of the late eighteenth century came to be produced "out of a formless clay, an inapt body." In this new schema, the soldier became a "machine" that could be produced and contained by, for example, teaching him to stand upright and to walk in an organized and calculated fashion. ${ }^{49}$ In describing the ways in which soldiers' bodies were transformed, Foucault reveals what he means by "discipline." The methods used to refashion the soldier from head to toe, which "made possible the meticulous control of the operations of the body, which assured the constant subjection of its forces and imposed upon them a relation of docility-utility, might be called 'disciplines.",50 Foucault writes that the production of subjected, docile bodies through disciplinary mechanisms had two effects. First, discipline created bodies that were more useful in terms of economic utilitythe forces of capitalism could harness their productive power. Second, from

45 Foucault, "Nietzsche, Genealogy, History," 148.

46 Foucault, Discipline and Punish, 136.

47 Judith Butler, Gender Trouble, 10th anniversary ed. (New York: Routledge, 1999), 175.

48 Foucault, Discipline and Punish, 135.

49 Ibid., 135-36.

so Ibid., 137. 
the perspective of political power, disciplined bodies were easier to controlthey were more obedient than pre-modern, indocile bodies. ${ }^{51}$

Harnessing the body has transformative potential and is part of a deeper project of power: the body becomes a channel for accessing the human soul and, subsequently, for endeavouring to control it. Foucault writes,

the man described for us, whom we are invited to free, is already in himself the effect of a subjection much more profound than himself. A "soul" inhabits him and brings him to existence, which is itself a factor in the mastery that power exercises over the body. The soul is the effect and instrument of a political anatomy; the soul is the prison of the body. 52

In Bodies That Matter, Butler helps to explain what, precisely, Foucault means by the "subjection" of the soul. She writes that "subjection" (assujettissement in French), involves not only a "securing and maintaining" but also the constitution of the soul of the subject. ${ }^{53}$ Foucault understands the soul to be another instrument of power, one that "forms and frames the body, stamps it, and in stamping it, brings it into being." 54

\section{Rosalyn Forrester's indocile body}

Unlike the paradigmatic soldier of the late eighteenth century, the body of Rosalyn Forrester has failed to conform to "norms" of docility. By failing to adhere to a strict, essentialist binary between male and female, Forrester's body is like that of a soldier who could not be harnessed, corrected, and fixed. In Forrester, the Ontario Human Rights Commission implicitly describes Forrester's body as a failure: she was born with male genitalia but adopted "norms" that we more readily associate with women. This logic of bodily failure reveals itself in the commission's uncritical acceptance of the evidence provided by Forrester's physicians, who "assess her as feeling real distress about her body, since it does not represent her gender to her."s5 The commission bolsters its claim about Forrester's 'broken' body by drawing a progressive, linear narrative from Forrester's experiences as a child to her present lived realities. We learn that, as a person existing in a 'failed' body, Forrester "dislikes seeing herself nude in the shower" and has "torn up her childhood photographs." 56 This disorderly, fractured divide between anatomical sex and self-perceived gender results in "strong feelings of discomfort" for Forrester. ${ }^{57}$

At one level, the commission's discussion of Forrester's "abnormal" or "distressing" body victimizes her--but at another level, the commission's

st Ibid.

52 Ibid., 30.

53 Butler, Bodies That Matter, 34.

54 Ibid. Note that "being" belongs in quotation marks, so as not to imply that ontological weight is presumed. Instead, ontological weight is constantly being conferred, such that it is always being constituted within and by an operation of power.

55 Forrester at para. 392.

56 lbid.

57 Ibid. at para. 393 
very words can be read differently, to suggest, rather, that Forrester's body has refused subjection and has rejected the coercive systems of power that would have her obediently learn to feel and look like a man despite not feeling herself to be one. Nobody else knows who Forrester really is; but her body, which worked as a disturbing and distressing sign, perhaps for her as well as for the police officers, could also be a sign of the failure of discipline and the emergence of something like agency.

\section{Correcting Rosalyn Forrester's Body}

Before encountering members of the Peel Regional Police during several strip searches, Rosalyn Forrester's indocile body, and perhaps even her indocile soul, had not succumbed to the coercive forces that would have her gender accord with her anatomical sex. However, as Foucault argues, "modest, suspicious power" is constantly being imposed on subjects, and so the battle was not over. ${ }^{58}$ For Foucault, three manifestations of this constantly operating type of power are hierarchical observation, normalizing judgment, and the examination. $^{59}$ In this section I argue that the strip searches imposed on Forrester represent precisely the sort of "correct training" described by Foucault. The strip searches imposed a normalized gaze on Forrester's trans body and, in doing so, sent a powerful message to those bodies and souls existing in both docile and indocile positions. The message was clear: those who do not adopt gendered "norms" based on their anatomy will be subjected to abusive, hyper-visible scrutiny, and so it is best not to challenge the existing power structures. ${ }^{60}$

\section{Hierarchical observation}

One way to control the actions of subjects is to observe them constantly and to open up the possibility for a "single gaze to see everything constantly.",6। Foucault's best-known example of the coercive potential of the singular gaze comes from Jeremy Bentham's model of the ideal prison: the Panopticon. The Panopticon is designed with a watchtower in the middle and cells encircling it. This design makes it impossible for the prisoners to know whether or not the guards are observing them at any given moment. Because prisoners never know whether or not they are being watched, Foucault contends, they will begin to modify their behaviour accordingly. And so the effect of the Panopticon is to "induce in the inmate a state of conscious and permanent visibility that assures the automatic functioning of power." To put it even more bluntly, prisoners begin to self-discipline:

58 Foucault, Discipline and Punish, 170.

59 Of course, there may be some dispute as to whether the overtly abusive strip searches forced upon Forrester are the sort of modest, suspicious episodes Foucault was interested in or whether they actually exemplify what Foucault would call "majestic rituals of sovereignty or the great apparatuses of the state." Ibid., 172.

60 For an interesting discussion of "working on ourselves" as a product of Foucaultian normalization of the body see, e.g., Cressida J. Heyes, Self-Transformations: Foucault, Ethics, and Normalized Bodies (Oxford: Oxford University Press, 2007).

6 Foucault, Discipline and Punish, 173. 
"inmates should be caught up in a power situation of which they are themselves the bearers." 62

The coercive potential of the perpetual gaze of others exists in a variety of contexts. For example, Laura Duhan Kaplan describes even exercise classes in Foucaultian terms:

In an aerobics class, there are no private spaces; interiority is not encouraged. Students observe their progress through a mirror, focusing on what others see, not on what they feel or think ... Aerobics encourages participants to see themselves as if they are imprisoned in the Panopticon: always subject to the gaze of the other, creating their own consciences, that is, their standards of self-evaluation, in response to what others see.

While an exercise class eventually ends, the coercive gaze of others, Foucault would argue, exists in perpetuity.

To be clear, Foucault argues that all members of modern society are constantly subjected to the gaze of others and that this gaze has the coercive effect of encouraging us to self-regulate. But Rosalyn Forrester experienced this gaze in a particularly acute way when she was forced to undergo a series of strip searches, many of which were conducted by insensitive, stereotypically masculine male police officers. ${ }^{64}$ The coercive nature of the gaze took a particularly violent turn during the third strip search. Forrester told the Human Rights Commission, "six male officers made demeaning comments to her, such as, 'oh, you liked it last time, you didn't mind last time,' and "you still have a dick so we can still search you.",65 After being released on bail, Forrester described being "roughed up" by the police and "forcibly searched," and "presented a bruise on her left deltoid muscle on her shoulder." 66

At the end of the commission's hearings, Forrester summed up the effect that the strip searches had on her in these words:

1 don't know how to describe how I felt, completely put out there, so everybody could see how I felt about what happened to me. As much as I need to move on and can go on with my life, and I don't feel like

62 Ibid., 201.

63 Laura Duhan Kaplan, "Physical Education for Domination and Emancipation: A Foucauldian Analysis of Aerobics and Hatha Yoga," in Philosophical Perspectives on Power and Domination: Theories and Practices, ed. Laurence F. Bove and Laura Duhan Kaplan (Amsterdam: Rodopi, 1997), 69-70. For a thoughtful discussion of contemporary regimes of self-regulation see, e.g., Brenda Cossman, Sexual Citizens: The Legal and Cultural Regulation of Sex and Belonging (Stanford, CA: Stanford University Press, 2007).

64 For a discussion of the gender politics implicated in policing see, e.g., Susan Ehrlich Martin; "Police Fonce or Police Service? Gender and Emotional Labor," Annals of the American Academy of Political and Social Science 561 (1999), 111; Frank Rudy Cooper, "Who's the Man? Masculinities and Police Stops" (Suffolk University Law School Research Paper No. 08-23, 2008), http://papers.ssm.com/sol3/papers.cfm? 65 abstract_id=1257183.

65 Forrester at para. 40.

66 Ibid. at para. 53 . 
getting off trains and buses when a man sits beside me ... I guess the best word 1 can come up with is "brutalized."67

Forrester's former physician, Dr Leah Steele, told the Human Rights Commission that when she met with Forrester shortly after the searches, Forrester was "compounded with anxieties" and "worr[ied] that she'd be harassed or killed by the police." ${ }^{, 68}$ Dr Steele also noted that Forrester's fear of the police compounded her social anxiety, and so she mostly stayed indoors for fear of suffering further abuse. Like the prisoners living in the shadow of the watchtower, Rosalyn Forrester began to selfregulate-when she went outside, she constantly experienced fear that more abuse was imminent.

\section{Normalizing judgment}

Normalizing judgment, a second technique of correct training, involves constant valuation and comparison among and between subjects. A rule or "norm" is constructed that functions as a "minimal threshold, as an average to be respected or as an optimum towards which one must move," and with this minimal threshold comes an incentive for subjects to conform: those who fail to conform constantly risk being codified as part of the "abnormal" or "shameful" class. "Humans who adopt social "norms" not only gain access to membership in a "homogeneous social body" but also begin to play a part in the "classification, [the] hierarchization and the distribution of rank.", Thus, the goal of normalized judgment is to make individual differences all but disappear by creating incentives for those who assimilate and punishments for those who do not.

There are several junctures at which mechanisms of power engulfed the indocile body of Rosalyn Forrester to impose standards of normalization on her. One potentially unexpected juncture, however, comes from the Ontario Human Rights Commission itself, during its discussion of the so-called gender determination. The logic that underpins the "gender determination" reifies an either/or understanding of gender, leaving little room for gender to exist on a fluid continuum.

Police officers who doubt the trans status of the detainee whom they are about to strip-search are instructed by the commission to pose a series of questions:

(1) What name appears on your identity documents?

(2) Have you disclosed your identity to your friends and/or family?

(3) Have you sought or are you seeking medical or professional guidance from a qualified professional? If so, can you give the name(s) of these people and their professional designations?

\footnotetext{
67 Ibid. at para. 361 .

68 lbid. at para. 54.

69 Foucault, Discipline and Punish, 183.

70 lbid., 184.
} 
(4) What steps are you taking to live full-time in a manner consistent with your gender identity? How can you demonstrate that you are living full-time in your gender identity?

(5) What is your gender identity and what medical steps, if any, have you taken to help your body match your gender identity? ${ }^{71}$

In these questions, the "norm" that anatomy (sex) and socially constructed expectations (gender) should always converge remains unchallenged. That is, the commission has left very little room for those who have more fluid conceptions of gender or who may not be in the privileged position of being able to obtain sexual reassignment surgery.

In addition, by creating a list of questions that police officers should pose to those trans subjects whose gender status they doubt, the commission has created an unfortunate hierarchy between the "deserving" trans person and the "undeserving" trans person. For example, the decision may work to exclude people who have not revealed their "gender status" to friends or family for fear of experiencing violence or abandonment. ${ }^{72}$ And so even the seemingly progressive judgment in Forrester ends up creating a benefit for those trans subjects who, for a variety of possible reasons, are able to present themselves as indocile but at least working diligently to "fix" themselves through surgery. Such detainees will have the opportunity to choose the gender of the officer who will strip-search them, whereas those who adopt more ambivalent or fluid approaches to gender will not be afforded the same opportunities. Thus the commission has implicitly created a hierarchy of trans subjects, a hierarchy that leaves the essentialist "norm" that gender must always accord with sex unchallenged and seems to encourage trans "fixing" through medical intervention.

\section{The examination}

The third and final mechanism for training docile bodies "combines the techniques of an observing hierarchy and those of a normalizing judgment.",73 Describing the examination, Foucault writes,

[i]t is a normalizing gaze, a surveillance that makes it possible to qualify, to classify and to punish. It establishes over individuals a visibility through which one differentiates them and judges them. That is why, in all the mechanisms of discipline, the examination is highly ritualized. In it are combined the ceremony of power and the form of the experiment, the deployment of force and the establishment of

71 Forrester at para. 436.

72 For a discussion of the class politics of gender reassignment surgery see, e.g., Katrina Roen, "'Either/Or' and 'Both/Neither': Discursive Tension in Transgender Politics," Signs 27 (2002), 501; Judith Butler, Undoing Gender (New York: Routledge, 2004), in particular her discussion of "Undiagnosing Gender," 75; Alaina Hardie, "It's a Long Way to the Top: Hierarchies of Legitimacy in Trans Communities," in Trans/Forming Feminisms: Trans-Feminist Voices Speak Out, ed. Krista Scott-Dixon (Toronto: Sumach Press, 2006), 122.

Foucault, Discipline and Punish, 184. 
truth. At the heart of the procedures of discipline, it manifests the subjection of those who are perceived as objects and the objectification of those who are subjected. ${ }^{74}$

Beyond deploying force and establishing truth, Foucault argues, disciplinary power also "imposes on those whom it subjects a principle of compulsory visibility." 75 Through the constant threat of making subjects visible by, for example, having every aspect of their lives described in excruciating detail, the "disciplined individual" begins to accept his or her subjection. Thus, the examination becomes yet another important mechanism in the discipline of subjects. $^{76}$

When the examination is finally completed, it

leaves behind it a whole meticulous archive constituted in terms of bodies and days. The examination, which places individuals in a field of surveillance, also situates them in a network of writing; it engages them in a whole mass of documents that capture and fix them.

Foucault calls this phenomenon the "power of writing." Disciplinary power first establishes codes, which serve to "formalize" the individual within power relations. Once the "norm" has been established, subjects are evaluated against fixed categories. This results in more written documentation and, thus, more visibility for those deemed "abnormal." liferation of writings on so-called abnormal subjects transforms each individual examination into a "case," one that is examined from every possible angle by those who sit in hegemonic positions of power. When the individual becomes a case, he or she can be "described, judged, measured, compared with others." Further, once made visible, the "cased" individual can begin to be "trained or corrected, classified, normalized, excluded, etc." Thus the examination becomes another tool in the discipline and subjection of bodies, especially those bodies that disrupt or otherwise threaten "norms."

The strip search of Rosalyn Forrester is a clear example of compulsory visibility for indocile trans bodies, a visibility that often takes the form of violence and coercive control. Take, for example, the treatment of Forrester during her second strip search. Forrester testified that the search was "conducted by all male officers even though she asked for a female officer to perform it and said that she had had a female officer search her earlier." Forrester was forced by several male police officers to reveal her indocile body. This process of revealing must be read as participation in the process

Ibid., 184-85.

Ibid., 187.

lbid., 187-89.

lbid., 189.

Ibid., 189-91.

Ibid., 191.

80 Forrester at para. 37. 
of correct training. The Ontario Human Rights Commission's decision outlines Forrester's testimony describing the search:

She said that [the male police officers] stood back, stared and snickered. Ms. Forrester testified that one of the officers said, "So what are you?" She said another officer made a comment about "transvestites." She said that one of the officers told her, "Well, you'd better get used to it because it's going to happen again today." She felt despondent and her voice broke when she testified that, "I felt like ending it.",

Echoing the language in Golden, Forrester later compared the strip searches to sexual assault, adding that she felt "like a freak in a zoo so they could stand there and go, ooh, ooh."

In a sense, the strip search imposed on Forrester represents two simultaneous movements: it deploys brutal force on Forrester's body while, at the same, it participates in the establishment of Forrester as a trans "species." ${ }^{83}$ The idea that the strip search represents two movements is supported by the police officers' reactions on encountering Forrester's body. The police officers snickered, which sent her a clear message that her body was so different and "abnormal" that it warranted their scorn. At the same time, her body was so "odd" that it required a closer gaze and a follow-up question from one police officer, who asked, "So what are you?" This impulse to want to gather as much information as possible about Forrester's body in its undressed state, from every possible angle, exemplifies what Foucault would call compulsory visibility. After scrutinizing Forrester's indocile body, the police began to compare it to other, more docile, bodies. The message was simple: Forrester's body would be scrutinized and questioned in ways that a body that accorded with normative conceptions of gender and sexuality would not. And so, as a Foucaultian examination, the strip searches imposed on Forrester's body reveal a coercive, disciplinary system invested in outlawing those bodies that fail to accord with hegemonic gender binaries.

\section{Conclusions: Refashioning Trans Agency}

Throughout my analysis I have argued that trans bodies--and, by extension, trans souls - symbolize a failure of the disciplinary regimes that engulf us all. These regimes work to codify, regulate, and coerce bodies, particularly those that symbolize non-normative versions of gender and sexuality. In Foucault's thought, there is no position outside the field of power, which may lead some to believe that we should merely give up and avoid the pursuit of concrete legal and political goals. Such a conclusion is erroneous: within our

Ibid. at para. 38 .

82 Ibid. at para. 39.

83 For an excellent discussion of "homosexuals" as a species produced by eighteenth-century discourse, see Michel Foucault, The History of Sexuality: An Introduction, vol. 1, trans. by Robert Hurley (New York: Vintage Books, 1978). 


\section{Kyle Kirkup}

constituted framework, there is certainly room for the exercise of individual agency, even if that agency is always being constituted by forces outside ourselves. Take, for example, Foucault's discussion of the construction of "homosexuality" as an identity category in The History of Sexuality. Foucault contends that homosexuality was once considered " the' great sin against nature. ${ }^{, 84}$ During the nineteenth century, the discursive formation of homosexuals as a type or "species" "made possible a strong advance of social controls into this area of "perversity." "85 But this is only part of the story; homosexuality also began to "speak on its own behalf, to demand that its legitimacy or 'naturality' be acknowledged, often in the same vocabulary, using the same categories by which it was medically disqualified." is, those who had been labelled as "deviant" began to refashion the systems of domination that had been imposed on them and, in the process, to undermine and subvert coercive systems of power.

In the search for concrete legal and political change for those dwelling in positions of non-normative gender and sexuality, the question we must pose is, How might we contribute to the agency of trans people when they are forced to undergo strip searches at the hands of the police? As I have hinted throughout my analysis, the first step, it seems, is to afford trans detainees the opportunity to self-identify for legal purposes. This reform strategy is precisely the one proposed by Lori Chambers. ${ }^{87}$ Chambers provides a thoughtful critique of Nixon v. Vancouver Rape Relief and Women's Shelter, ${ }^{88}$ in which a trans woman argued that she had been discriminated against when she was excluded from a "women-only" space. Regarding self-identification as a strategy for reform, Chambers states that "[i]f women-only space is to survive, 'woman' must be left open to determination. Otherwise, we are engaging in policing and exclusion that is detrimental to the promotion of universal human rights."

To be clear, the decision in Forrester is a step in the right direction in promoting trans agency - it affords self-identified trans detainees the choice of male officers, female officers, or a "split search" during strip searches. However, that right is unduly limited by a problematic caveat: the detainee's choice can be undermined if police officers doubt his or her self-identification. Even worse, those who are doubted must submit to a series of intrusive questions during the so-called gender determination. When these caveats are read together, it becomes clear that the vision of trans agency offered by the Ontario Human Rights Commission is a deeply impoverished one. A more meaningful version of trans agency would have made trans self-identification the only relevant consideration in determining whether or not the three choices would be offered to the detainee prior to the strip search.

Ibid., 101.

Ibid.

lbid.

Lori Chambers, "Unprincipled Exclusions: Feminist Theory, Transgender Jurisprudence, and Kimberly Nixon," Canadian Journal of Women and the Law 19 (2007), 305.

[2002] B.C.H.R.T.D. No. I.

Chambers, "Unprincipled Exclusions," 333. 
ldentifying the problem of trans strip searches and providing a reform proposal must be understood as one piece of a much larger process of creating space so that those dwelling in non-normative positions of gender and sexuality can begin to exercise their agency. While there are no simple answers, the complexity of the problem and the difficulty of introducing concrete solutions should be a source of invigoration, not paralysis. By allowing for the exercise of trans agency during strip searches, we can begin to contribute to a larger project of undermining existing structures of corporeal power, structures that engulf all human beings.

\title{
Résumé
}

Cet article se penche sur la question des sexes non normatifs et des sexualités dans le contexte du monde complexe des procédures criminelles. S'appuyant sur une lecture de Forrester v. Peel (Regional Municipality) Police Services Board et al, soit une décision récente où une prisonnière transsexuelle alléguait avoir subi une discrimination en raison de son sexe, cet article fait le lien entre les fouilles à nu et un système plus large de pouvoir corporel. Les corps " trans " sont ciblés non seulement parce qu'ils sont perçus comme différents mais aussi parce que cette différence symbolise quelque chose de particulier, à savoir un échec des régimes qui réglementent les corps à partir d'une construction binaire, rigide et essentialiste du sexe. Ainsi, les corps « trans " deviennent à la fois la cible d'observations, de normalisations et d'examens non seulement de la part de la police, mais aussi de la société dans son ensemble.

Mots clés: transsexualité, fouilles à nu, police, sexualité, minorités

\begin{abstract}
This article examines what happens when non-normative genders and sexualities collide with the complicated world of criminal procedure. Grounded in a close reading of Forrester v. Peel (Regional Municipality) Police Services Board, a recent decision in which a trans detainee alleged discrimination in services on the basis of "sex," the article connects strip searches to a larger system of corporeal power. Trans bodies are targeted not merely because they are perceived as different but also because of what that difference symbolizes: a failure of the regimes that regulate bodies into a sharp, essentialist gender binary. As such, trans bodies become a key site for simultaneous observation, normalization, and examination not only by the police but also by society at large.
\end{abstract}

Keywords: transgender, strip searches, police, sexuality, minorities

Kyle Kirkup

Faculty of Law, Common Law

University of Ottawa

57 Louis Pasteur Street

Ottawa, ON K1N 6N5 Canada

kkirk100@uottawa.ca 